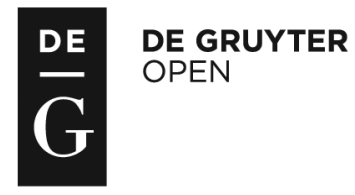

Administration, vol. 63, no. 2 (2015), pp. 79-99

doi: 10.1515/admin-2015-0011

\title{
Women in local government: Moving in from the margins
}

\author{
Fiona Buckley \\ University College Cork \\ Caroline Hofman \\ University College Cork
}

\begin{abstract}
This article presents a descriptive overview of women's participation in the elected and administrative structures of local government in the Republic of Ireland. Drawing on analysis of candidate data and electoral results from the 2014 local elections, it shows that women's political representation currently stands at just under 21 per cent, a record high for women's participation in the elected structures of county and city councils. The article evaluates the lessons learned about political parties, gender and candidate recruitment at the 2014 local elections. It argues that the impending introduction of legislative gender quotas at the next general election was the main driving force behind women's increased participation in these elections. Turning attention to the administrative structures of local authorities, it is revealed that men continue to dominate senior management positions. While increasing numbers of women are accessing senior management roles, gendered barriers remain. The article concludes by reflecting on the future prospects for women's participation in both the elected and administrative structures of local government in the Republic of
\end{abstract}


Ireland. It recommends an extension of legal gender quotas to local elections and a more proactive gender promotional and mentoring campaign within local government administrative structures.

Keywords: Women and local government, gender quotas, 2014 local elections, candidate selection, women in management

\section{Introduction}

The story of women's participation in local government dates back to the late nineteenth century and the passage of the Local Government (Ireland) Act, 1898. Under this Act, women were granted the right to vote and stand in election for the first time. As Crossman (1994) notes in her book Local Government in Nineteenth-Century Ireland, local government was the scene for some early successes by the Irish suffragist movement, with the first elections in 1899 returning thirtyone women district councillors and eighty-five women as poor law guardians. Despite these early achievements, the social conservatism that pervaded Irish political culture and society for much of the twentieth century resulted in social and legal barriers for women accessing work outside the home and entering into public life. The introduction of the so-called 'marriage bar' in 1932 significantly limited women's employment opportunities. This Act forced women working in the 'civil service, health and local authorities' (Galligan, 1998, p. 30) to resign from their jobs upon marriage. Gendered practices and norms within political parties saw women relegated to support functions (if they were present at all) and largely overlooked for electoral office (McGing, 2014). The impact of these gendered legacies and institutional norms are borne out in the fact that today just one in five councillors are women and it was 1998 before a woman was appointed to the role of local authority manager, ${ }^{2}$ nearly seventy years after men first began to occupy such positions.

This article profiles women's current participation in the elected and administrative structures of local government in the Republic of Ireland. Drawing on analysis of candidate data and electoral results

1 The 1932 marriage bar initially required national school teachers to retire on marriage but the bar was extended to the whole public service thereafter. In 1958 national school teachers became exempt from the bar, and the bar was removed from the full public service in 1973.

2 The title of county/city manager was replaced by the term of chief executive under provisions of the Local Government Reform Act, 2014. 
from the 2014 local elections, it evaluates the lessons learned about political parties, gender and candidate recruitment at those elections. There were 128 more women candidates contesting the 2014 local elections than in 2009, with the number of women councillors increasing to $197,{ }^{3}$ well up on the number of women who were elected at the 2009 (146) and 2004 (151) elections. We argue that the impending introduction of legislative gender quotas at the next general election was the main reason behind women's increased candidacy and election in the 2014 local elections. However, wide variations remain in terms of political party selection of women candidates and the geographical representation of women. We contend that an extension of legislative gender quotas to local government may need to be considered to overcome these variations. Turning attention to the administrative structures of local authorities, it is revealed that men continue to dominate senior management positions. The article examines why women are under-represented in senior management and considers the future prospects for women's participation in the senior administrative structures of local government in the Republic of Ireland.

\section{4 local elections: Women councillors}

Following the 2014 local elections, women occupy just under 21 per cent of the 949 council seats in the Republic of Ireland. While the results represent a record high for women's political representation in county and city councils, they still place the Republic of Ireland below the EU28 average of 32 per cent for women's representation in local politics. A closer examination of the results reveals that 28 of the 137 local electoral areas are represented by all-male slates of councillors,

\footnotetext{
3 This figure represents the number of women elected in the local elections on 23 May 2014 and the delayed running of the Ballybay-Clones electoral area on 7 June 2014. At the time of writing, in April 2015, the number of women councillors had increased to 198. On the day of the local election Ruth Coppinger (Anti-Austerity Alliance) was elected as both a councillor in the Mulhuddart electoral area and a member of Dáil Éireann for the constituency of Dublin West. She took her seat in Dáil Éireann and Matthew Waine was subsequently co-opted onto Fingal County Council in August 2014. In January 2015 Deborah Callaghan (Fianna Fáil) was co-opted onto Kildare County Council for the Naas electoral area following the death of her father, Councillor Willie Callaghan, in December 2014. In March 2015 Gaye Fagan (Sinn Féin) was co-opted onto Dublin City Council for the North Inner City electoral area following the resignation of Councillor Jonathan Dowdall for health reasons.
} 
no council reached gender parity and just 6 of the 31 councils had a female chair in the 2014/15 council year. ${ }^{4}$

Table 1: Female and male councillors per party, 2014 and 2009

\begin{tabular}{lrrrrrrr}
\hline Party & Total & $\begin{array}{c}2014 \\
\text { Women } \\
(\%)\end{array}$ & $\begin{array}{c}\text { Men } \\
(\%)\end{array}$ & $\begin{array}{c}\text { Total } \\
\text { Women } \\
(\%)\end{array}$ & \multicolumn{1}{c}{$\begin{array}{c}\text { Men } \\
(\%)\end{array}$} \\
\hline Fine Gael & 234 & $50(21.4)$ & $184(78.6)$ & 340 & $59(17.4)$ & 281 & $(82.6)$ \\
Fianna Fáil & 266 & $36(13.5)$ & $230(86.5)$ & 218 & $31(14.2)$ & 187 & $(85.8)$ \\
Sinn Féin & 160 & $48(30.0)$ & $112(70.0)$ & 54 & $11(20.4)$ & 43 & $(79.6)$ \\
Labour & 51 & $17(33.3)$ & $34(67.7)$ & 132 & $29(22.0)$ & 103 & $(78.0)$ \\
Greens & 12 & $3(25.0)$ & $9(75.0)$ & 3 & $0(0)$ & $3(100.0)$ \\
Independents/ & & & & & & \\
Others & 226 & $43(19.0)$ & $183(81.0)$ & 136 & $16(11.8)$ & 120 & $(88.2)$ \\
Total & $\mathbf{9 4 9}$ & $\mathbf{1 9 7}(\mathbf{2 0 . 8})$ & $\mathbf{7 5 2} \mathbf{( 7 9 . 2 )}$ & $\mathbf{8 8 3}$ & $\mathbf{1 4 6}(\mathbf{1 6 . 5})$ & $\mathbf{7 3 7}$ & $\mathbf{( 8 3 . 5 )}$ \\
\hline
\end{tabular}

Source: Data sourced from Kavanagh (2014). The compilation of table and calculations are authors' own.

Note: At the 2014 local elections People Before Profit elected fourteen councillors: six women and eight men. Thirteen councillors were elected for the Anti-Austerity Alliance: four women and nine men.

Table 1 disaggregates the results by gender and party. The 2014 local elections saw a total of 197 women elected, representing a 35 per cent increase on the number of women elected in 2009. The backlash against the governing parties saw Fine Gael lose over 30 per cent of its seats, with the number of Fine Gael women councillors decreasing by nine to fifty. Despite this numerical decrease, Fine Gael still has the highest number of women councillors at the local level and women make up just over 21 per cent of Fine Gael councillors, an increase of four percentage points since 2009. Sinn Féin has the second-highest number of women councillors. Forty-eight women were elected to represent the Sinn Féin party, a significant increase on the eleven Sinn Féin women councillors elected in 2009. Women now make up 30 per cent of Sinn Féin councillors, an increase of ten percentage points since 2009. While the number of Fianna Fáil women councillors increased from thirty-one in 2009 to thirty-six in the most recent contest, the figures represent a decrease in the percentage of female Fianna Fáil councillors to just over 13 per cent. The collapse in the

\footnotetext{
${ }^{4}$ The word 'chair' is used here as a collective term to represent the variety of titles across the county and city councils, including cathaoirleach, chairperson, lord mayor and mayor.
} 
national vote for Labour saw the party lose over 60 per cent of its seats. Labour's women councillors were reduced to seventeen. However, the severity of seat losses was less for Labour women than it was for Labour men. Women now make up a third of Labour councillors, an increase of eleven percentage points since 2009.

A notable outcome in these elections was the increase in the number of women elected from smaller parties and as independents. Three women were elected for the Green Party, an increase from the nadir election of 2009 when no women were elected for the party. Six women were elected to represent the People Before Profit Alliance, an increase of four since 2009. In 2009 just one woman was elected for the Socialist Party. In 2014 four women were elected under the AntiAusterity Alliance banner. Overall, the percentage of women elected under the 'Independents/Others' group grew to 19 per cent, an increase of approximately eight percentage points since 2009.

Examining women's representation across the thirty-one local authorities reveals that only three have achieved a so-called critical mass status of 30 per cent or more women councillors. These are Dún Laoghaire-Rathdown (43 per cent), South Dublin (33 per cent) and Dublin City (32 per cent). Donegal lags at the bottom of the femalerepresentation league table with just over 8 per cent women councillors, followed by Offaly and Clare on 10 per cent and 11 per cent, respectively. There is a notable urban-rural divide in terms of female-representation levels. A third of all women councillors are based in the Dublin region, followed by Leinster (19 per cent), Connaught (19 per cent), Munster (18 per cent) and Ulster (11 per cent) (Kavanagh, 2014). A review of electoral areas reveals that some of the highest female political representation rates were recorded in urban centres or in areas with a large county town, notably Crumlin-Kimmage (67 per cent), Blackrock (67 per cent), Rathfarnham (67 per cent), Castleknock (57 per cent), Dundalk South (57 per cent), Mulhuddart (50 per cent), Boyle (50 per cent) and Greystones (50 per cent).

\section{4 local elections: Women candidates}

A total of 2,031 candidates contested the 2014 local elections - 1,591 men and 440 women. While men continued to significantly outnumber women candidates, there were more women contesting these elections than in 2009. On that occasion 314 of the total number of candidates were women. 
Table 2 disaggregates candidate numbers and percentages by party. A review of female candidacy rates across the parties shows that women comprised just under 23 per cent of Fine Gael candidates (up from 18 per cent in 2009), 17 per cent of Fianna Fáil candidates (relatively the same as in 2009), just under 32 per cent of Sinn Féin candidates (up from 23 per cent in 2009) and 29 per cent of Labour candidates (up from 23 per cent in 2009). Women made up just over 18 per cent of candidates running for smaller parties and as independents, including People Before Profit (approximately 39 per cent) and the Anti-Austerity Alliance (30 per cent). Just under a third of the Green Party's candidates were women.

Table 2: Female candidates per party/grouping, 2014 and 2009

\begin{tabular}{lccc}
\hline Party & $\begin{array}{c}2014 \text { Women } \\
(\%)\end{array}$ & $\begin{array}{c}2009 \text { Women } \\
(\%)\end{array}$ & $\begin{array}{c}\text { Difference } \\
\text { (percentage points) }\end{array}$ \\
\hline Fine Gael & 22.6 & 18.1 & +4.5 \\
Fianna Fáil & 17.1 & 16.9 & +0.2 \\
Sinn Féin & 31.6 & 22.8 & +8.8 \\
Labour & 29.1 & 23.1 & +6 \\
Greens & 32.6 & 22.1 & +10.5 \\
Independents/Others & 18.3 & 10.8 & +7.5 \\
Total & $\mathbf{2 1 . 7}$ & $\mathbf{1 7 . 2}$ & $+\mathbf{4 . 5}$ \\
\hline
\end{tabular}

Source: Data sourced from Kavanagh (2014). The compilation of table and calculations are authors' own.

Note: Women comprised 38.6 per cent of People Before Profit candidates and 30 per cent of Anti-Austerity Alliance candidates.

In two electoral areas women candidates outnumbered men: Blackrock, where seven of the eleven candidates were women; and Rathfarnham, where six of the eleven candidates were women. Dún Laoghaire, Mulhuddart, East Cork, Greystones, Ballybay-Clones, Ballymun and Stillorgan all recorded good gender balance in their candidate lists (Kavanagh, 2014). However, voters in five electoral areas were presented with all-male tickets: Newcastle West, Muinebeag, Athlone (Roscommon), Athlone (Westmeath) and Ballinasloe.

\section{4 local elections: Candidate selection and gender recruitment}

While men continued to outnumber women in terms of candidacy and councillors in the 2014 local elections, these elections did register an 
improvement on the low level of female candidacy and representation associated with previous local election contests. We argue that the reason to account for the increase is the Electoral (Amendment) (Political Funding) Act, 2012. The law was introduced to address the very low levels of women's participation in politics in the Republic of Ireland. Currently the country ranks in eighty-third position in an international league table for women's parliamentary representation (Inter-Parliamentary Union, 2015). The Act specifies that at the next Dáil election a gender quota will apply which obliges political parties to select at least 30 per cent male candidates and at least 30 per cent female candidates. If not, political parties will lose half of the state funding they receive on an annual basis to run their operations. The quota will rise to 40 per cent seven years after the next Dáil election. While the law is not applicable at the local level, it appears that many of the political parties sensibly used the 2014 local elections to recruit and run women candidates. This can be understood as a contagion or diffusion effect of the gender quota law, whereby political parties voluntarily adopted gender targets for the local elections. Gender targets ranged from 25 per cent in the case of Fine Gael to 30 per cent in the case of Labour and Sinn Féin. In its Gender Equality Action Plan (2013) Fianna Fáil reiterated a commitment made in 2005 to ensure women made up a third of its candidates by the 2014 local elections.

A review of the candidate figures reveals that only Sinn Féin met and exceeded its informal gender target. The Labour Party came close, just missing its target by 1 per cent. Fine Gael fell short of its target, an inexcusable situation for a party with a membership consisting of over 40 per cent women, the highest of the four main political parties. However, the biggest disappointment in terms of female candidate selection was Fianna Fáil. With just 17 per cent women candidates, the party fell well short of its self-imposed gender target, but most revealingly the party made only a minimal increase on the percentage of women candidates it selected in 2009. Smaller parties such as People Before Profit, the Anti-Austerity Alliance and the Green Party all cleared the 30 per cent threshold.

What does all of this tell us about the current state of gender and candidate recruitment in Irish political parties? Firstly, there is a clear left-right demarcation in terms of political parties' inclination to select women candidates. This conforms to the international experience, where studies have shown that political parties of a centre-left and leftist ideology are more likely to recruit and select women candidates (Kittilson, 2006; Krook, 2010; Opello, 2006). 
Secondly, two of the longest-established political parties in the state were least likely to select women candidates. Political parties are institutions and, similar to all institutions, they have their own distinct ideologies, cultures and norms (Childs \& Webb, 2012). Long-term institutional legacies and gendered practices within political parties can serve to sideline women's contributions to those of support functions, rather than leadership and electoral roles. Newer political parties, free of the gendered legacies of more established parties, may be more facilitating of women's ascension into leadership and candidacy positions.

Thirdly, the use of equality strategies (Lovenduski, 2005), such as promotional activities targeted at women party members, the presence of a dedicated women's section and the use of gender guarantees, do work to increase women's candidacy within political parties. Thirty years prior to most of its political counterparts, the Labour Party was using 'interventionist measures' with the imposition of a 25 per cent gender target for the 1985 local elections (Buckley, 2013, p. 348). While the party has not always met its gender targets, the early adoption of such feminising strategies has ensured that it is in a better position than other long-established parties, such as Fianna Fáil and Fine Gael, to meet its obligations under the Electoral (Amendment) (Political Funding) Act, 2012. In addition, the organisational presence of Labour Women, a dedicated women's faction within the party, acts as a strong force of gendered mobilisation, and aids the supply of women candidates through network building, training and support programmes (McGing, 2014). Women sections in other parties have largely been under-resourced, some have been disbanded, while others have had their roles expanded to encompass wider equality issues.

Fourthly, the discourse around gender quotas and the underrepresentation of women in politics may be acting as a motivating factor for women to put themselves forward for election. This may help explain the eight percentage point increase in women's candidacy in the 'Others/Independents' category since 2009. However, a more nuanced reason may explain the strong showing of women amongst candidates for the Anti-Austerity Alliance and People Before Profit Parties. A 2012 study by Ursula Barry and Pauline Conroy showed that the economic downturn and the government responses to tackling it have disproportionately affected women. We may be witnessing a situation where increasing numbers of women, having experienced first-hand the acute impact of government cutbacks, are putting 
themselves forward for election to highlight the impact of the economic downturn on people's lives.

\section{4 local elections: Lessons learned}

The overall increase in the number of women candidates saw a corresponding increase in the number of women councillors elected. This augurs well for the next general election when the legal gender quota applies.

As well as the party variations highlighted in the previous section, there were also notable geographical variations in terms of female candidacy and election, with women more likely to run and win seats in more urbanised areas of the country. While further research is required to outline the precise reasons for this, we can hypothesise that a double bind of cultural expectations and distance is a factor. Conservative cultural attitudes in rural areas about the role of women in politics may stymie the selection prospects of female candidates in these areas. More generally the continuing bias towards traditional gender roles in Ireland means women still undertake the majority of care work (Galligan, 2010). As highlighted in the Oireachtas report Women's Participation in Politics (Bacik, 2009), this is a key factor affecting the supply of women into politics, as women with heavy care responsibilities do not have the same level of time available to dedicate to politics as those without care responsibilities. However, rural-based women with care duties face the added issue of lack of proximity to council and constituent meetings. Rural electoral districts encompass relatively large geographical areas. Depending on one's location within the electoral area, councillors can face long travel distances to attend meetings, which eats into time spent on other activities. In comparison to urban-based women, rural-based women with heavy care responsibilities and lack of proximity to meetings may be less likely to put themselves forward as electoral candidates.

Table 3 disaggregates candidate success rates by gender and party. Overall, the success rate for women candidates was just under 45 per cent, over 2 per cent less than that for male candidates. The highest male and female success rates were recorded in Sinn Féin and Fianna Fáil, reflecting a good day at the polls for both parties. However, examining candidate success rates within and between the various parties/groupings shows that female candidate success rates were higher than male candidate success rates in the Labour Party, People Before Profit, Anti-Austerity Alliance and amongst 
Table 3: Candidate success rates by party and gender, 2014

\begin{tabular}{|c|c|c|c|c|}
\hline Party & $\begin{array}{c}\text { All } \\
\text { success } \\
\text { rate } \\
(\%)\end{array}$ & $\begin{array}{c}\text { Female } \\
\text { success rate } \\
\text { (gap b/w all } \\
\text { \& female) } \\
(\%)\end{array}$ & $\begin{array}{c}\text { Male } \\
\text { success rate } \\
\text { (gap b/w all } \\
\& \text { male) } \\
(\%)\end{array}$ & $\begin{array}{c}\text { Gender gap } \\
\text { (gap b/w female } \\
\& \text { male) } \\
\text { (percentage } \\
\text { points) }\end{array}$ \\
\hline Fine Gael & 49.9 & $47.2(-2.7)$ & $50.7(+0.8)$ & -3.5 \\
\hline Fianna Fáil & 64.1 & $50.7(-13.4)$ & $66.9(+2.8)$ & -16.2 \\
\hline Sinn Féin & 81.6 & $77.4(-4.2)$ & $83.6(+2.0)$ & -6.2 \\
\hline Labour & 26.9 & $30.9(+4.0)$ & $25.4(-1.5)$ & +5.5 \\
\hline People Before Profit & 31.8 & $35.3(+3.5)$ & $29.7(-2.1)$ & +5.6 \\
\hline Greens & 26.1 & $20.0(-6.1)$ & $29.0(+2.9)$ & -9.0 \\
\hline Anti-Austerity Alliance & 32.5 & $33.3(+0.8)$ & $32.1(-0.4)$ & +1.2 \\
\hline Independents/Others & 31.5 & $32.4(+0.9)$ & $31.3(-0.2)$ & +1.1 \\
\hline Total & 46.7 & $44.8(-1.9)$ & $47.3(+0.6)$ & -2.5 \\
\hline
\end{tabular}

Source: Authors' own calculations.

'Independent/Other' candidates. The opposite was the case in Fianna Fáil, Fine Gael, Sinn Féin and the Green Party, where female candidates recorded lower success rates than their male counterparts. Further vote analysis and research on incumbency effects are required to explain these gender gaps but the headline figures may indicate that more men than women were selected to run for winnable seats in Fianna Fáil, Sinn Féin and Fine Gael, while the converse was the case in Labour and smaller parties such as People Before Profit and the Anti-Austerity Alliance.

As well as having a potential mobilising effect on women, the discourse surrounding gender quotas and women's under-representation in politics may also be giving women the platform and the confidence to speak up and speak out about life within political parties and their personal experiences of politics more generally. During the course of the 2014 local and European election campaign Senator Averil Power wrote an article in The Irish Times outlining her disappointment at Fianna Fáil's failure to implement its own gender equality action plan, a document published in 2013 setting out a series of steps to increase the number of women contesting elections for the party (Power, 2014)..$^{5}$ Lorraine Clifford, a Fianna Fáil candidate in the Pembroke-South Dock local electoral area spoke up about the 'vile abuse' she received from a member of the public about her

5 On 25 May 2015 Averil Power resigned from the Fianna Fáil party. Among the reasons she provided for her resignation was that the strategy she was 'asked to develop on improving female participation in the party had largely been ignored' (Power, 2015). 
appearance and pregnancy (Duffy, 2014). Senator Lorraine Higgins, a Labour Party candidate in the European Parliament elections, spoke out about a 'death threat' she received during the election campaign and her belief that such comments are 'directed towards women more so' than men (Calnan \& Sheahan, 2014).

\section{Why does this all matter?}

Localism is an important aspect of Irish politics. The Irish National Election Study has consistently found that 'localness' and the ability to look after the needs of one's constituency are key considerations in voter decision-making (www.tcd.ie/ines). Localism is also a significant aspect of candidate selection processes for Dáil elections. Local government experience is considered vital if one is to put oneself forward for candidate selection at the national level. It provides individuals with the opportunity to develop key resources such as local support networks, campaign skills and name recognition. A study of the 2007 and 2011 Dáil elections by Buckley et al. shows that a total of 76 per cent of male candidates elected to the Dáil had local government experience. The corresponding figure for women was 81 per cent. In 2011 alone, nine out of ten women elected as TDs had prior experience of local government. Thus, local government is a significant springboard for women wishing to run for Dáil elections (Buckley et al., forthcoming).

Table 4: Women councillors elected at local elections, 1974-2014

\begin{tabular}{lc}
\hline Election year & $\begin{array}{c}\text { Women's seat-holding } \\
(\%)\end{array}$ \\
\hline 1974 & 6 \\
1979 & 6 \\
1985 & 8 \\
1991 & 12 \\
1999 & 15 \\
2004 & 19 \\
2009 & 17 \\
2014 & 21 \\
\hline
\end{tabular}

Sources: Manning (1987, pp. 158, 160), Kavanagh (2014) and authors' own calculations.

However, the number of women with local government experience remains low. Table 4 presents data on the percentage of women 
elected to local government over the past forty years. Up to the 1990s, the percentage of local government seats held by women was in the single digits. A breakthrough occurred in 1991 when the percentage of women councillors rose to 12 per cent. Changing societal attitudes and a greater awareness of women in politics as a consequence of Mary Robinson's election as Ireland's first woman president a year earlier contributed to this increase. Female seat-holding steadily rose in the years that followed. By 2004, 19 per cent of councillors were women. However, this fell back to 17 per cent following the 2009 local elections. In May 2014 women won just under 21 per cent of the seats. Given that men still dominate in local office seat-holding, relatively few women are in a position to use local offices as a springboard to national office (Buckley et al., forthcoming). Considering the importance of localism and local government experience for candidate selection for Dáil elections, the government may need to consider an extension of legislative gender quotas to local elections to ensure that a steady supply of suitably qualified women are available to contest Dáil elections.

\section{Gender and senior management in local government in the Republic of Ireland}

Nearly seventy years after Philip Monahan was appointed manager to Cork Corporation in 1929, the Republic of Ireland saw the appointment of its first woman local authority manager. In 1998 Ann McGuinness was appointed manager of Westmeath County Council. Historically, senior management in local government has been a maledominated sphere. To explain this, one must go back to 1925 when women's right to paid employment was 'limited by the Irish government'. The passage of the 1925 Civil Service Regulation (Amendment) Bill put women at a great disadvantage, with employment opportunities limited 'on the grounds of sex' largely due to 'the ongoing crisis in male employment during the period of the 1920s' (Galligan 1998, p. 31). The introduction of the so-called 'marriage bar' in 1932 further limited female employment opportunities as this formally excluded married women from 'employment in the public service and the administrative system'. Women working in the 'civil service, health and local authorities' were forced to resign their jobs upon marriage (Galligan, 1998, p. 30). Changing attitudes and the influence of the EU (then known as the European Economic Community) led to the 'expansion of Irish 
women's employment and political opportunities' in the 1970s (Gardiner, 1999, p. 38). The marriage bar was lifted in 1973 and the Employment Equality Act was introduced in 1977. This Act prohibited discrimination in most areas of employment based on gender or marital status (Galligan, 1998).

However, the legacy of these restrictive laws can still be seen in the Irish public services. Former county manager Martina Moloney, speaking about the marriage bar, has said, 'there would probably be more women rising to higher roles in recent years only for it' (Dowling, 2013). The upper echelons of management are still dominated by men. The 2013 Women and Men in Ireland Report showed that 70 per cent of persons employed as managers, directors and senior officials were men (Central Statistics Office, 2014). A survey conducted by the Irish Independent in 2013 revealed that of 2,258 people on salaries of $€ 50,000$ or more in Irish local authorities, 71 per cent were men (Popham et al., 2013).

In April 2015 six women held the title of local authority chief executive in the Republic of Ireland, accounting for approximately 19 per cent of all chief executives. These were Jackie Maguire in Meath County Council, Philomena Poole in Dún Laoghaire-Rathdown County Council, Ann Doherty in Cork City Council, Colette Byrne in Offaly County Council, Joan Martin in Louth County Council and Moira Murrell in Kerry County Council. In total, eight women have served as head of a local authority in the Republic of Ireland (see Table 5).

Examining the current ${ }^{6}$ gender profile of senior management teams across the local authorities reveals that Laois County Council, Leitrim County Council and Louth County Council are the most gender balanced, with 50 per cent of the senior management positions in these authorities held by women. Dún Laoghaire-Rathdown and Fingal County Councils have good records in this regard too, with women occupying over 40 per cent of the senior management positions in these local authorities. In twenty-three local authorities there is at least one woman in the senior management team. In thirteen local authorities women head up the important finance or director of services position. However, a quarter of all local authorities have no women in their senior management team. ${ }^{7}$

\footnotetext{
${ }^{6}$ April 2015.

${ }^{7}$ Data sourced from local authority websites, minutes of council meetings, and emails and phone calls to local authorities in March and April 2015.
} 
Table 5: Women county/city managers/chief executives appointed to local authorities in the Republic of Ireland

\begin{tabular}{llc}
\hline Name & City/county council & Year of appointment \\
\hline Ann McGuinness & Westmeath & 1998 \\
Martina Moloney & Louth & 2003 \\
Jackie Maguire & Leitrim & 2006 \\
Martina Moloney & Galway County & 2007 \\
Jackie Maguire & Meath & 2013 \\
Philomena Poole & Louth & 2013 \\
Philomena Poole & Dún Laoghaire-Rathdown & 2014 \\
Ann Doherty & Cork City & 2014 \\
Colette Byrne & Offaly & 2014 \\
Joan Martin & Louth & 2014 \\
Moira Murrell & Kerry & 2014 \\
\hline
\end{tabular}

Sources: Data sourced from council websites, minutes of council meetings and newspaper reports, both national and local. The authors strived to compile as comprehensive and as accurate a list as possible. Authors take full responsibility for any inaccuracies and omissions.

Note 1: Philomena Poole took up the position as county manager of Louth County Council in 2013 but in early 2014 announced that she would be moving to Dún Laoghaire-Rathdown County Council after being offered the position of county manager there.

Note 2: A number of women have also served as acting county/city managers, including Martina Moloney (Galway City), Theresa White (Cork County), Bernie O'Brien (Carlow), Philomena Poole (South Dublin), Katherine Holohan (Dún Laoghaire-Rathdown) and Dorothy Clarke (Sligo).

\section{Continuing gendered barriers to reaching senior management}

An increasing number of women are making it to the top of the public service but the pace of change is slow. For the most part, women are still 'concentrated in the lowest-paid jobs, the temporary, part-time and casualised jobs', and the majority of minimum wage workers in the Republic of Ireland are women (McKay, 2008, p. xv). Women earn on average 14 per cent less than men, are nearly three times more likely than men to be in part-time work in Ireland and make up the overwhelming majority ( 80 per cent) of clerical workers (Eurostat, 2015).

Research has shown that 'women do not succeed in bureaucratic organisations for a host of reasons that are internal to the dynamics of organisations themselves', with these reasons 'including indirect and direct discrimination, gender stereotyping of senior managerial 
positions, exclusion from key gendered social networking events and the gender segregation of occupational role' (Lynch \& Lyons, 2008, pp. 163-4). Gender stereotypes and perceptions are described as continuing to be a barrier. The Department of Justice and Equality's Towards Gender Parity report notes that 'beliefs surrounding the cultural roles traditionally held by women and men, particularly in relation to childcare and care of other dependants, have a detrimental effect on women's advancement in the workforce' (Department of Justice and Equality, 2013, p. 31).

The gendered nature of organisational culture is another major issue to contend with, and offers an important understanding of 'why women are not moving upwards within the management and administrative structures' (O'Connor, 1996, p. 205). Davies (1995, p. 44) suggests that in this context organisations must be seen as 'social constructions that arise from a masculine vision of the world and that call on masculinity for their legitimation and affirmation'. Women work within these masculine frameworks, moving up the ranks 'ignoring difference, acting as equal' (Davies, 1995, p. 37) as they do so, becoming 'surrogate men' (Carey, 1994). Although this strategy may prove to be successful at an individual level, 'it leaves the hegemonic patriarchal culture intact, and is inherently fragile, since such women's status as honorary males may of course be withdrawn at any moment' (O'Connor, 1996, p. 206).

The Towards Gender Parity report has expressed concern about the 'lack of female role models in decision-making positions', with this having the consequence of affecting and influencing 'self-selection among other women who perceive that there are few opportunities for women in senior management and so exclude themselves from going forward for promotion or training programmes'. The report calls on successful female role models to 'inspire other women to push themselves to attain positions in senior management, on company boards and in politics' (Department of Justice and Equality, 2013, p. 39).

Women also face a combination of 'glass ceilings' and 'sticky floors', whereby 'women participate in paid work in numbers equal to men' but 'appear to be excluded from the top jobs' (Bratton et al., 2010, p. 225). The Glass-Ceiling Index for women and work in 2014 identified the Nordic countries of Finland, Norway and Sweden to be the best places for a woman to work. Ireland, on 53.6 per cent, was behind and below the OECD average of 60 per cent (R. L. W., \& D. H., 2015). 
However, it is the issue of care that still acts as a significant gendered barrier to female promotional opportunities. Women undertake the majority of care work in the Republic of Ireland. Data from the 2013 Women and Men in Ireland Report show that employment rates for men and women aged between twenty and forty-four with no children are relatively the same (approximately 86 per cent). However, the employment rates of men and women aged between twenty and forty-four with a child aged between four and five indicate a 24.5 per cent gender gap, with male employment rates at 76.2 per cent but female employment rates falling to 51.7 per cent (Central Statistics Office, 2014). The issue of childcare was examined by the Joint Committee on Women's Rights in 1991 and the subsequent report pointed 'to the problems of motherhood and the difficulties in reconciling home and career as being a significant barrier to women's promotional opportunities in the state bureaucracy' (Galligan, 1999, p. 16). However, nearly twenty-five years later, childcare is still a major issue, in particular the crippling costs associated with childcare. Jones (2014) describes the cost of childcare as a 'new marriage bar' for female participation in the workforce.

\section{Discussion and conclusion: Future prospects for women's participation in local government}

While Better Local Government: A Programme for Change (Department of the Environment, Heritage and Local Government, 1996, p. 6) stated that 'a special development programme will be established with the aim of increasing the number of women managers in local authorities', this was not implemented (Connelly, 2011, p. 64). ${ }^{8}$ Men continue to dominate senior management in Irish local authorities. Bernard Harbor, IMPACT ${ }^{9}$ spokesperson, quoted in the Irish Independent in August 2013, noted that 'the 2012 workforce planning report by the County and City Managers' Association says little or

\footnotetext{
8 Connelly explains that the stalling of the specialised development programme for women was attributed to the alteration of the promotional landscape for all staff introduced by Better Local Government. In light of this, it was decided to proceed with a 'development programme for all senior management staff', meaning that the 'urgently required development course, which would have been specific to female needs', was never introduced (Connelly, 2011, p. 46).

${ }^{9}$ IMPACT is one of Ireland's largest public service trade unions but also represents workers in voluntary and community sectors, semi-state organisations and the private sector.
} 
nothing about gender imbalance in local authority grades' (Popham et al., 2013). This is reflective of a wider issue whereby the focus of government gender equality plans tends to be concentrated on the Dáil and state board level.

Apart from a pledge to assist those with young families by arranging meetings at family-friendly times, Putting People First (Department of the Environment, Community and Local Government, 2012) was weak on concrete proposals to advance women in local government. However, if the government is serious about achieving a critical mass of women in the Dáil, it is essential that more women contest and get elected to local government.

As noted in this article, local government is the feeder or pipeline for politicians wishing to pursue a political career at the national level. The Electoral (Amendment) (Political Funding) Act, 2012, did create a contagion effect at the 2014 local elections, with most political parties increasing their number of women candidates. However, there were wide party and geographical variations in terms of female candidacy and representation. The government may need to extend legislative gender quotas to the local level to address these variations. Such a move would bring the Republic of Ireland into line with other states that have adopted gender quotas in recent years, the majority of whom apply gender quotas at the local level in addition to the national level. The dual approach guarantees a supply of quality female candidates from local level, with proven track records, electoral experience and name recognition, to contest elections at the national level. It also forces the grassroots levels of political parties to treat the issue of women's political under-representation with more sincerity, challenging them to assess the gender profile of their own branches and compelling them to engage in more activities to recruit and maintain women members. This can contribute to minimising the geographical variations.

A gender equality document published by Fianna Fáil in January 2015 recommended that a bill should be put forward to ensure 'a candidate gender quota is introduced at local government level so as to secure the supply of experienced women candidates' (Fianna Fáil, 2015, p. 6). This is welcome but considering its own challenges with meeting its voluntary gender target in 2014, it will be interesting to observe how far Fianna Fáil will champion the extension of gender quotas to local government.

Any extension of the legal gender quota to local government would require a penalty to ensure compliance. The acute financial penalty 
associated with the Dáil gender quota is unlikely to apply at the local level unless there is a change to the laws surrounding the state funding of political parties. Currently the state funding of parties is related to performance at Dáil elections only. ${ }^{10}$

Tackling the issue of women's participation in local authority management requires a more nuanced approach. Unlike public life, where there is an issue of supply of women into politics, women access the public service in equal numbers to men. However, like politics, the issue of childcare remains a gendered barrier to women's promotional opportunities. Proposals ranging from tax breaks for parents and the provision of capitation grants to crèches have been suggested to tackle the high costs involved, averaging $€ 888$ per baby per month (Sheehan, 2015). Sociologists in the US have found evidence that mothers can be disadvantaged in terms of promotion as employers view them as more committed to children and family than work (Ridgeway \& Correll, 2004). Paid paternity leave and increasing shared parental leave entitlements may go some way to changing organisational attitudes towards mothers. The government is currently looking at proposals to introduce a full year's paid parental leave, which would see a six-month extension to the current maternity benefit to be shared between parents. This is a welcome move.

Greater objectivity in promotional rounds, with the inclusion of a gender audit of female and male candidates' qualifications and essential criteria for positions, should become a regular feature of selection processes. Similar to government targets for women on state boards (40 per cent), gender targets for women in senior management should also be considered.

\section{Acknowledgements}

The authors wish to acknowledge the work of Adrian Kavanagh, whose blog, Irish Elections: Geography, Facts and Analyses, was a huge asset when compiling data for this article. The authors also wish to acknowledge Meryl Kenny and Fiona Mackay's 2012 article 'Less Male, Pale and Stale? Women and the 2012 Scottish Local Government Elections', which provided a very useful guide for the structure of this article.

10 Under the Electoral Acts, state funding is made available to registered political parties which poll 2 per cent or more of the first-preference vote at the preceding general election. 


\section{Notes}

Aspects of this paper were contained in a number of newspaper articles that Fiona Buckley contributed to in the lead up to the 2014 local elections, including articles in the Evening Echo (April 2014), The Irish Times (May 2014) and the Irish Examiner (May 2014).

\section{References}

Bacik, I. (2009). Women's participation in politics. Retrieved from http://www.oireachtas.ie/documents/committees30thdail/jjusticeedwr/repo rts_2008/20091105.pdf [26 June 2015].

Barry, U., \& Conroy, P. (2012). Ireland: Untold story of the crisis - Gender equality and new inequalities. Dublin: TASC.

Bratton, J., Sawchuk, P., Forshaw, C., Callinan, M., \& Corbett, M. (2010). Work and organizational behaviour (2nd ed.). Basingstoke: Palgrave MacMillan.

Buckley, F. (2013). Women and politics in Ireland: The road to sex quotas. Irish Political Studies, 28 (3), 341-59.

Buckley, F., Mariani, M., McGing, C., \& White, T. J. (forthcoming). Is local office a springboard for women to Dáil Éireann? Journal of Women, Politics and Policy.

Calnan, D., \& Sheahan, F. (2014, May 28). Labour candidate got death threats during EU campaign. Retrieved from http://www.independent.ie/irishnews/politics/labour-candidate-got-death-threats-during-eu-campaign30309999.html [27 April 2015].

Carey, M. (1994). Gender and power: Boys will be boys and so will girls. Irish Journal of Sociology, 4, 105-27.

Central Statistics Office. (2014). 2013 women and men in Ireland report. Retrieved from http://www.cso.ie/en/releasesandpublications/ep/pwamii/womenandmeninireland2013/ [28 April 2015].

Childs, S., \& Webb, P. (2012). Sex, gender and the Conservative Party: From iron lady to kitten heels. Basingstoke: Palgrave Macmillan.

Connelly, J. (2011). The impact of public sector reform on gender equality in Ireland: A case study of Cork City Council. Administration, 59 (1), 39-68.

Crossman, V. (1994). Local government in nineteenth-century Ireland. Belfast: Institute of Irish Studies.

Davies, C. (1995). Gender and the professional predicament in nursing. Buckingham: Open University Press.

Department of Justice and Equality. (2013). Towards gender parity in decisionmaking in Ireland. Retrieved from http://www.justice.ie/en/JELR/ FINALTowards $\% 20$ Gender $\% 20$ Parity.pdf/Files/FINALTowards $\% 20 \mathrm{Gen}$ der\%20Parity.pdf [5 March 2015]. 
Department of the Environment, Community and Local Government. (2012). Putting people first: Action programme for effective local government. Dublin: Department of the Environment, Community and Local Government.

Department of the Environment, Heritage and Local Government. (1996). Better local government: A programme for change. Dublin: Department of the Environment, Heritage and Local Government.

Dowling, E. (2013, August 26). County manager Martina broke the mould to get top job. Retrieved from http://www.independent.ie/irish-news/countymanager-martina-broke-the-mould-to-get-top-job-29527625.html [27 April 2015].

Duffy, R. (2014, May 16). Local election candidate subjected to 'vile abuse' for being pregnant. Retrieved from http://www.thejournal.ie/local-electionslorraine-clifford-1468600-May2014/ [27 April 2015].

Eurostat. (2015). Women earned on average 16\% less than men in 2013 in the EU. Retrieved from https://static.rasset.ie/documents/news/eurostat-genderpay-gap.pdf [28 April 2015].

Fianna Fáil. (2013). Gender equality action plan. Dublin: Fianna Fáil.

Fianna Fáil. (2015). Markievicz Commission report: Gender equality document. Dublin: Fianna Fáil.

Galligan, Y. (1998). Women and politics in contemporary Ireland: From the margins to the mainstream. London: Pinter.

Galligan, Y. (1999). Women in political, economic and social decision-making in Ireland. Midleton: Litho Press.

Galligan, Y. (2010). Women in politics. In J. Coakley \& M. Gallagher (Eds), Politics in the Republic of Ireland (5th ed.; pp. 263-91). London: Routledge.

Gardiner, F. (1999). The impact of EU equality legislation on Irish women. In Y. Galligan, E. Ward \& R. Wilford (Eds), Contesting politics: Women in Ireland, north and south (pp. 38-54). Oxford: Westview Press.

Inter-Parliamentary Union. (2015). Women in national parliaments. Retrieved from http://www.ipu.org/wmn-e/classif.htm [27 April 2015].

Jones, J. (2014, November 12). Second opinion: Inequality, abuse and the cost of childcare preserve the marriage bar. Retrieved from http://www.irish times.com/life-and-style/health-family/second-opinion-inequality-abuseand-the-cost-of-childcare-preserve-the-marriage-bar-1.1989270 [25 March 2015].

Kavanagh, A. (2014) Irish elections: Geography, facts and analyses. Retrieved from http://adriankavanaghelections.org/author/adriankavanagh/ [27 April 2015].

Kenny, M., \& Mackay, F. (2012). Less male, pale and stale? Women and the 2012 Scottish local government elections. Scottish Affairs, 80, 20-32.

Kittilson, M. C. (2006). Challenging parties, changing parliaments: Women and elected office in contemporary Western Europe. Columbus OH: Ohio State University Press.

Krook, M. L. (2010). Why are fewer women than men elected? Gender and the dynamics of candidate selection. Political Studies Review, 8 (2), 155-68.

Lovenduski, J. (2005). Feminizing politics. Cambridge: Polity. 
Lynch, K., \& Lyons, M. (2008). The gendered order of caring. In U. Barry (Ed.), Where are we now? New feminist perspectives on women in contemporary Ireland (pp. 163-83). Dublin: New Island Press.

Manning, M. (1987). Women and the elections. In H. R. Penniman \& B. Farrell (Eds), Ireland at the polls, 1981, 1982, and 1987: A study of four general elections (pp. 156-66). Durham: Duke University Press.

McGing, C. (2014). Women's roles in Irish political parties: Continuity and change. In C. Fischer \& M. McAuliffe (Eds), Irish feminisms: Past, present and future (pp. 189-215). New York: Syracuse University Press.

McKay, S. (2008). Introduction. In U. Barry (Ed.), Where are we now? New feminist perspectives on women in contemporary Ireland (pp. xi-xxii). Dublin: New Island Press.

O'Connor, P. (1996). Organisational culture as a barrier to women's promotion. The Economic and Social Review, 27 (3), 205-34.

Opello, K. A. R. (2006). Gender quotas, parity reform, and political parties in France. New York: Lexington.

Popham, H., Dowling, E., \& Melia, P. (2013, August 26). Just 10pc of top local authority jobs held by women. Retrieved from http://www.independent.ie/ irish-news/just-10pc-of-top-local-authority-jobs-held-by-women29526747.html [27 April 2015].

Power, A. (2014, April 2). Why Fianna Fáil isn't meeting local election target on female candidates. Retrieved from http://www.irishtimes.com/news/politics/ why-fianna-f\%C3\%A1il-isn-t-meeting-local-election-target-on-femalecandidates-1.1746169 [27 April 2015].

Power, A. (2015, May 27). Averil Power: Party's reaction confirms that I made right decision. Retrieved from http://www.irishexaminer.com/viewpoints/ analysis/averil-power-partys-reaction-confirms-that-i-made-right-decision333100.html [26 June 2015].

Ridgeway, C. L., \& Correll, S. J. (2004). Motherhood as a status characteristic. Journal of Social Issues, 60 (4), 683-700.

R. L. W., \& D. H. (2015, March 5). Daily chart: The glass-ceiling index. Retrieved from http://www.economist.com/blogs/graphicdetail/2015/03/ daily-chart-1 [25 March 2015].

Sheehan, A. (2015, 3 January). Working parents need to be earning $€ 30,000$ just to cover childcare costs. Retrieved from http://www.independent.ie/business/ personal-finance/latest-news/working-parents-need-to-be-earning-30000just-to-cover-childcare-costs-30879215.html [28 April 2015]. 